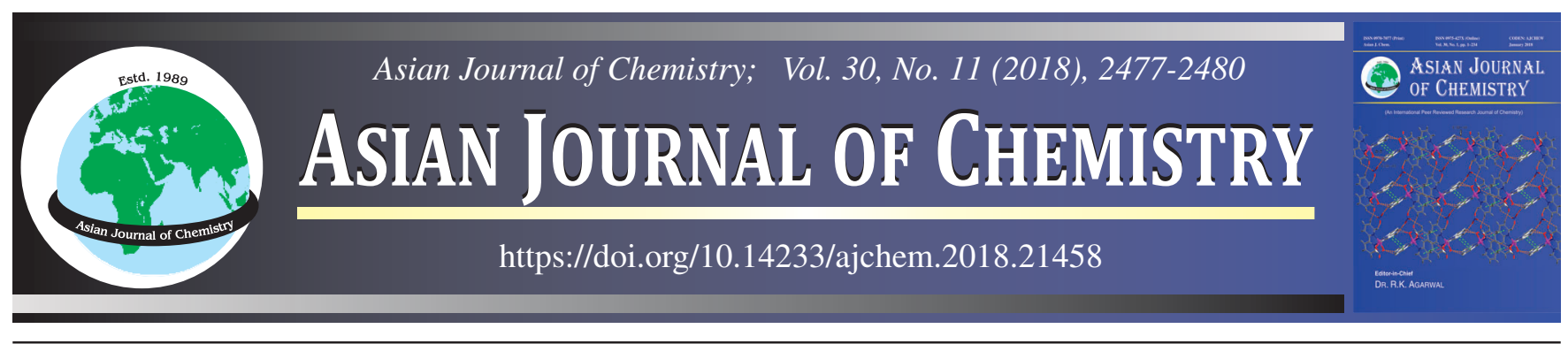

\title{
Optimization of Extraction Process and Simultaneous Determination of Flurbiprofen and Methyl Salicylate in Marketed Topical Gel Formulation by Vierodt's Method
}

Shivani Sawant, Karishma Naik and P.N. Sanjay Pai*

Department of Pharmaceutical Analysis, Goa College of Pharmacy, Panaji-403 001, India

*Corresponding author: E-mail: pnsanjaypai@gmail.com

Received: 18 May 2018;

Accepted: 19 July 2018;

Published online: 27 September 2018;

AJC-19098

Flurbiprofen (FLB) and methyl salicylate (MS), the actives in a commercial topical gel formulation were extracted for their simultaneous estimation. The extraction system was optimized, validated for elimination of interferences associated with matrix materials used in the formulation and also compensate for possible interference of one drug by the other during analysis. An efficient extraction procedure was developed for the separation of flurbiprofen and methyl salicylate from the marketed formulation Brugel and analyzed for the content with a new validated vierodt's simultaneous equation method. Detection wavelengths of 248 and 304 nm were used for recording the absorbance as they represent the absorption maxima of flurbiprofen and methyl salicylate respectively. Simultaneous equations were designed to estimate the unknown concentration of both the components in the marketed formulation. Linearity was calculated using standard stock solution of methyl salicylate and flurbiprofen in the concentration range of $5-30 \mu \mathrm{g} / \mathrm{mL}$. The developed method was found to be specific, precise, accurate and can be used for routine analysis of flurbiprofen and methyl salicylate in marketed gel formulations.

Keywords: Flurbiprofen, Methyl salicylate, Gel, Extraction, Simultaneous equation.

\section{INTRODUCTION}

Flurbiprofen is used in muscle-skeletal and joint disorders such as ankylosing spondylitis, osteoarthritis and rheumatoid arthritis, in soft-tissue disorders such as sprains and strains and for postoperative pains [1,2]. Flurbiprofen is mostly administrated orally. One disadvantage of the oral administration of flurbiprofen comprising compositions is that the patient is likely to experience unpleasant side effects, including gastrointestinal irritation. The use of flurbiprofen in treating local pains and inflammations may cause a problem especially for those who have gastrointestinal system disorders. It is possible to develop various locally-administrable topical forms of flurbiprofen, in order to avoid the systemic side-effects thereof [3]. Methyl salicylate is used to provide relief from aches and pains in mostly muscle-skeletal, joint and soft-tissue disorders [4]. One form of topical formulations being gel, has been widely used due to the specific advantages that they offer over other topical formulations like creams, sprays, or plasters, being ease of preparation, patient compliance and the advantage of incorporating a wide variety of drugs. Topical NSAIDs penetrate the skin, enter tissues or joints and reduce processes causing pain in the tissue. Drug levels in the blood with topical NSAIDs are very much lower than with the same drug taken by mouth. This minimizes the risk of harmful effects. Analysis of actives in gel formulations throws challenges to the analyst on account of possible interferences associated with the complexity of the matrix materials used. Therefore the objectives of the study involved extraction of the actives flurbiprofen and methyl salicylate in a commercial topical gel formulation and its optimization, for elimination of interferences associated with matrix materials used in the making of the formulation and simultaneous estimation of flurbiprofen and methyl salicylate for purpose of routine analysis.

On survey of literature, no method could be found for simultaneous analysis of flurbiprofen and methyl salicylate in gel formulations. However HPLC [5-12], HPTLC [13], GC-MS [14], GLC [15], UV [16-18], spectrofluorimetry [19] and FT-Raman [20] methods are reported for simultaneous analysis of flurbiprofen with other drugs and UV spectroscopy for methyl salicylate [21]. Analysis of other NSAID's from topical preparations have been found in the literature,

This is an open access journal, and articles are distributed under the terms of the Creative Commons Attribution-NonCommercial 4.0 International (CC BY-NC 4.0) License, which allows others to copy and redistribute the material in any medium or format, remix, transform, and build upon the material, as long as appropriate credit is given and the new creations are licensed under the identical terms. 
prominent being diclofenac in gel formulations has been estimated by UPLC [22], ketorolac tromethamine in topical formulations by HPLC $[23,24]$ and indomethacin gel formulation by HPLC [25]. In all the topical formulations, the extraction of the drug from the gel matrix needs optimization for accuracy in analysis.

\section{EXPERIMENTAL}

Flurbiprofen was obtained as a gift sample from Indoco Remedies. Methyl salicylate AR (Loba Chemie), acetonitrile HPLC-spectroscopy grade (SD Fine) and potassium dihydrogen phosphate (Chemport Chemicals) were used. Marketed gel formulation, Brugel (30g) by Abbott Pharmaceuticals was purchased from the market.

Shimadzu UV spectrophotometer (UV-2700 equipped with UV Probe 2.51 software) and $\mathrm{pH}$ meter, Labtronics (LT10) were used during the studies.

\section{Preparation of buffer}

0.02 M Sodium hydroxide ( $\mathrm{NaOH}): 0.2 \mathrm{~g}$ of $\mathrm{NaOH}$ was dissolved in $250 \mathrm{~mL}$ of distilled water in a $250 \mathrm{~mL}$ flask.

$0.02 \mathrm{M}$ phosphate buffer (pH 4): Potassium dihydrogen phosphate $(0.272 \mathrm{~g})$ was weighed and dissolved in a $100 \mathrm{~mL}$ volumetric flask using distilled water. The $\mathrm{pH}$ of the solution was adjusted to $\mathrm{pH} 4$ using orthophosphoric acid and the volume was made up to $100 \mathrm{~mL}$ using distilled water.

0.02 M phosphate buffer (pH 5): Potassium dihydrogen phosphate $(0.272 \mathrm{~g})$ was weighed and dissolved in a $100 \mathrm{~mL}$ volumetric flask using distilled water. The $\mathrm{pH}$ of the solution was adjusted to $\mathrm{pH} 5$ using $0.02 \mathrm{M} \mathrm{NaOH}$ and the volume was made up to $100 \mathrm{~mL}$ using distilled water.

0.02 M phosphate buffer (pH 6): Potassium dihydrogen phosphate $(0.272 \mathrm{~g})$ was weighed and dissolved in a $100 \mathrm{~mL}$ volumetric flask using distilled water. The $\mathrm{pH}$ of the solution was adjusted to $\mathrm{pH} 6$ using $0.02 \mathrm{M} \mathrm{NaOH}$ and the volume was made up to $100 \mathrm{~mL}$ using distilled water.

$0.02 \mathrm{M}$ phosphate buffer (pH 7): Potassium dihydrogen phosphate $(0.272 \mathrm{~g})$ was weighed and dissolved in a $100 \mathrm{~mL}$ volumetric flask using distilled water. The $\mathrm{pH}$ of the solution was adjusted to $\mathrm{pH} 7$ using $0.02 \mathrm{M} \mathrm{NaOH}$ and the volume was made up to $100 \mathrm{~mL}$ using distilled water.

Optimization of buffer concentration: Buffer, $0.02 \mathrm{M}$ $\mathrm{KH}_{2} \mathrm{PO}_{4}$ of $\mathrm{pH}$ ranging from 4 to 7 were used for the study as they produced clear solutions. Phosphate buffer at $\mathrm{pH} 4$ and beyond in high acid medium gave turbid solutions while extraction of the drug from gel, hence were not used for further studies. The absorptivity of the drug at detection wavelength is presented in Table-1.

TABLE-1

ABSORPTIVITY OF MS (x) AND FLURBIPROFEN (y) AT $\mathrm{pH}$ OF BUFFER USED DURING EXTRACTION FROM GEL FORMULATION

\begin{tabular}{ccccc}
\hline $\begin{array}{c}\mathrm{pH} \text { of buffer used } \\
\text { during extraction }\end{array}$ & $\mathrm{ax}_{1}$ & $\mathrm{ax}_{2}$ & $\mathrm{ay}_{1}$ & $\mathrm{ay}_{2}$ \\
\hline 5 & 307 & 357 & 726 & 0 \\
6 & 322 & 363 & 740 & 3 \\
7 & 313 & 350 & 729 & 7 \\
\hline
\end{tabular}

Preparation of standard methyl salicylate and flurbiprofen solutions

Methyl salicylate (MS): For standard stock solution, 0.1 $\mathrm{g}(0.085 \mathrm{~mL})$ of methyl salicylate was accurately weighed in to a $100 \mathrm{~mL}$ std flask, $40 \mathrm{~mL}$ of acenotrile was added and the substance dissolved, further $0.02 \mathrm{M}$ phosphate buffer ( $\mathrm{pH}$ 6) was added to make up the volume to obtain concentration of 1 $\mathrm{mg} / \mathrm{mL}$.

Flurbiprofen (FLB): For stock solution, $0.01 \mathrm{~g}$ of flurbiprofen was weighed and transferred to a $10 \mathrm{~mL}$ volumetric flask, to which $4 \mathrm{~mL}$ of acenotrile was added and further $0.02 \mathrm{M}$ phosphate buffer ( $\mathrm{pH}$ 6) was added to make the volume to obtain concentration of $1 \mathrm{mg} / \mathrm{mL}$.

Linearity plots were drawn from appropriate dilutions made with std stock solutions of methyl salicylate and flurbiprofen. Std stock flurbiprofen and methyl salicylate $0.05 \mathrm{~mL}$, was diluted in std $10 \mathrm{~mL}$ flask to volume with the solvent mixture (2:3) to obtain concentration of $5 \mu \mathrm{g} / \mathrm{mL}$. Similarly $0.1,0.15,0.2,0.25,0.3 \mathrm{~mL}$ was diluted separately in std flasks to obtain concentrations of 10 to $30 \mu \mathrm{g} / \mathrm{mL}$. The absorbance was recorded at 248 and $304 \mathrm{~nm}$.

For designing the Vierodt's equation, the absorbance for both flurbiprofen and methyl salicylate was recorded at 304 and $248 \mathrm{~nm}$ separately and corresponding absorptivity calculated.

$$
\begin{aligned}
\mathrm{C}_{\mathrm{X}} & =\frac{\mathrm{A}_{2} \mathrm{ay}_{1}-\mathrm{A}_{1} \mathrm{ay}_{2}}{\mathrm{ax}_{2} \mathrm{ay}_{1}-\mathrm{ax}_{1} \mathrm{ay}_{2}} \\
& =\frac{\mathrm{A}_{2}(739.85)-\mathrm{A}_{1}(2.8)}{363.25 \times 739.85-322.7 \times 2.8} \\
& =\frac{\mathrm{A}_{2}(739.85)-\mathrm{A}_{1}(2.8)}{267846.95} \\
\mathrm{C}_{\mathrm{Y}} & =\frac{\mathrm{A}_{1} \mathrm{ax}_{2}-\mathrm{A}_{2} \mathrm{ax}_{1}}{\mathrm{ax}_{2} \mathrm{ay}_{1}-\mathrm{ax}_{1} \mathrm{ay}_{2}} \\
& =\frac{\mathrm{A}_{1}(357.2)-\mathrm{A}_{2}(307.3)}{267846.95}
\end{aligned}
$$

where, $A_{1}=$ Absorbance of gel extract at $\lambda_{1}(248 \mathrm{~nm}) ; A_{2}=$ Absorbance of gel extract at $\lambda_{2}(304 \mathrm{~nm}) ; \mathrm{ax}_{1}=$ Absorptivity of methyl salicylate at $248 \mathrm{~nm} ; a_{2}=$ Absorptivity of methyl salicylate at $304 \mathrm{~nm} ; a_{1}=$ Absorptivity of flurbiprofen at 248 $\mathrm{nm} ; \mathrm{ay}_{2}=$ Absorptivity of flurbiprofen at $304 \mathrm{~nm} ; \mathrm{C}_{\mathrm{x}}=$ Concentration of methyl salicylate; $\mathrm{C}_{\mathrm{Y}}=$ Concentration of flurbiprofen.

Procedure for extraction from gel: About $1 \mathrm{~g}$ of Brugel was weighed in to $10 \mathrm{~mL}$ volumetric flask and further $6 \mathrm{~mL}$ of 'solvent' comprising mixture of acetonitrile and $0.02 \mathrm{M}$ phosphate buffer, $\mathrm{pH} 6$ in ratio of 2:3 was added. The contents were shaken for $20 \mathrm{~min}$ and further sonicated for $10 \mathrm{~min}$. The volume was made up to the mark with the solvent to obtain sample stock solution. Further working sample solution was prepared by diluting $0.1 \mathrm{~mL}$ of sample stock to $100 \mathrm{~mL}$ with $0.02 \mathrm{M}$ phosphate buffer ( $\mathrm{pH}$ 6.6) in a std flask and absorbance $\left(\mathrm{A}_{1}\right.$ and $\mathrm{A}_{2}$ ) recorded at 248 and $304 \mathrm{~nm}$.

Method validation: Linearity was determined at six concentration levels of $5-30 \mu \mathrm{g} / \mathrm{mL}$ for both methyl salicylate and 
flurbiprofen. Accuracy of the method was determined at three levels of $80,100,120 \%$ of the test concentration and the percent recovery calculated. For the recovery study, $1 \mathrm{~mL}$ of the previously analyzed gel extract was transferred to a $10 \mathrm{~mL}$ std flask, to which calculated amount of the standard was spiked and volume made up with $0.02 \mathrm{M}$ phosphate buffer (pH 6).

For precision studies, $1 \mathrm{~mL}$ of working standard was transferred to a series of $10 \mathrm{~mL}$ standard flask and volume made up using $0.02 \mathrm{M}$ phosphate buffer ( $\mathrm{pH}$ 6). Absorbance of the solutions was measured against the blank at 248 and $304 \mathrm{~nm}$.

\section{RESULTS AND DISCUSSION}

Solubility studies for flurbiprofen and methyl salicylate was done in common solvents used in spectroscopy like water, $0.1 \mathrm{~N} \mathrm{HCl}, 0.1 \mathrm{~N} \mathrm{NaOH}$ and methanol. Buffered medium of $\mathrm{pH}$ ranging from 4 to 7 was provided during extraction of the drugs from the gel formulation. Based on the solubility, clarity of solutions and optimum absorbance a mixture of ACN: 0.02 $\mathrm{M}$ phosphate buffer $\mathrm{pH} 6$ (in ratio of 2:3) was selected as the extraction solvent and used for the studies. Absorption maxima of 304 and $248 \mathrm{~nm}$ were recorded for methyl salicylate and flurbiprofen respectively (Fig. 1).

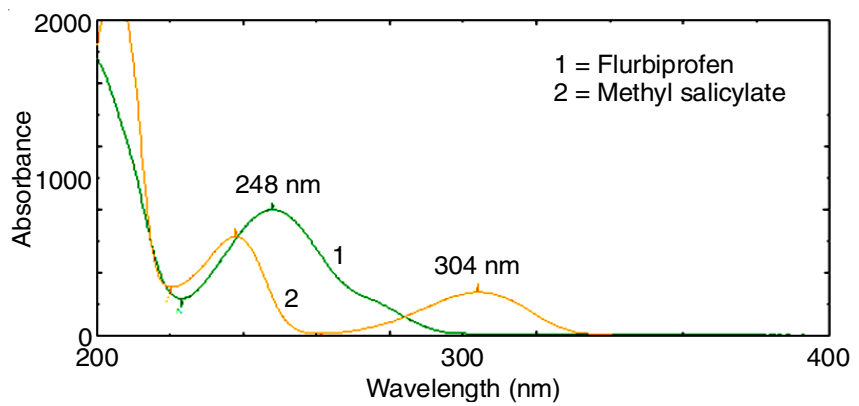

Fig. 1. Overlain UV spectrum of flurbiprofen and methyl salicylate

The developed method was validated for linearity, range, accuracy and precision. Linearity was determined using standard stock solution of methyl salicylate (Fig. 2) and flurbiprofen (Fig. 3) in the concentration range of $5-30 \mu \mathrm{g} / \mathrm{mL}$. Equation of the calibration curve was found to be $\mathrm{y}=0.0361 \mathrm{x}$ +0.0011 and $y=0.0664 x+0.0744$, with $r^{2}$ value of 0.999 and 0.992 for methyl salicylate and flurbiprofen respectively. For Accuracy of the method, the percentage recovery ranged from 96.51 to $98.15 \%$ for methyl salicylate and 97.32 to $101.35 \%$ for flurbiprofen. Precision studies were conducted for repeatability of the method, giving \% RSD of 0.99 and 1.42 for flurbiprofen and methyl salicylate respectively, both of which were found to be NMT $2 \%$. Amount of flurbiprofen and methyl salicylate was found to be $0.071 \mathrm{~g}(7.1 \%)$ and $0.076 \mathrm{~g}(7.6 \%)$ respectively in $1 \mathrm{~g}$ of the gel formulation (label claim $5 \%$ of flurbiprofen), as presented in Table-2.

\section{Conclusion}

It is found that extraction process of active's from gel matrix is $\mathrm{pH}$ and buffer concentration dependent. Slight changes in $\mathrm{pH}$ results in incomplete extraction of the active compounds as found from the results of the studies. The current study has shown optimum release of both flurbiprofen and

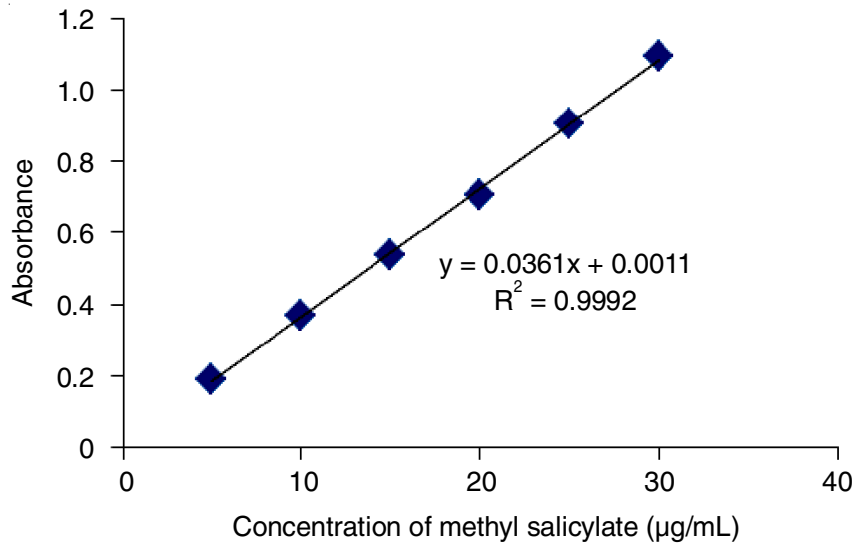

Fig. 2. Linearity plot of methyl salicylate at $304 \mathrm{~nm}$

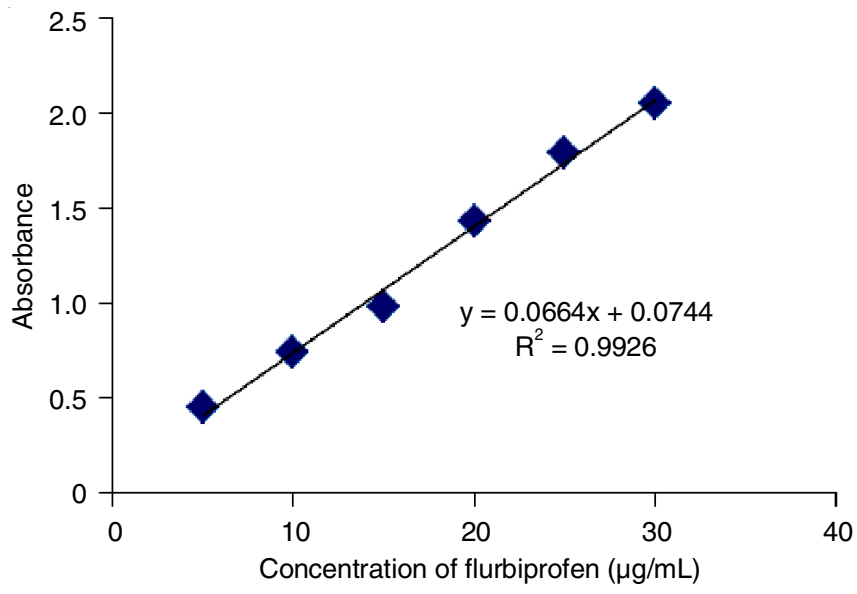

Fig. 3. Linearity plot of flurbiprofen at $248 \mathrm{~nm}$

TABLE-2

CONCENTRATION OF METHYL SALICYLATE AND FLURBIPROFEN IN GEL FORMULATION

\begin{tabular}{cccc}
\hline \multirow{2}{*}{$\begin{array}{c}\text { Absorbance } \\
\text { at } 248 \mathrm{~nm} \\
\left(\mathrm{~A}_{1}\right)\end{array}$} & $\begin{array}{c}\text { Absorbance } \\
\text { at 304 nm } \\
\left(\mathrm{A}_{2}\right)\end{array}$ & \multicolumn{2}{c}{$\begin{array}{c}\text { Concentration of } \\
\text { actives in gel formulation }\end{array}$} \\
\hline 0.779 & 0.280 & $\begin{array}{c}\text { Methyl } \\
\text { salicylate (x) }\end{array}$ & $\begin{array}{c}\text { Flurbiprofen (y) } \\
\text { (label claim: 5\%) }\end{array}$ \\
\hline
\end{tabular}

methyl salicylate when $0.02 \mathrm{M}$ phosphate buffer, $\mathrm{pH} 6$ is used during the extraction process. The optimized Vierodt's method can be successfully used for routine analysis of flurbiprofen in gel formulations in presence of methyl salicylate.

\section{CONFLICT OF INTEREST}

The authors declare that there is no conflict of interests regarding the publication of this article.

\section{REFERENCES}

1. R.A. Moore, S. Derry and H.J. McQuay, Rheum. Dis. Clin. North Am., 34, 415 (2008);

https://doi.org/10.1016/j.rdc.2008.03.006.

2. C.M. Lee and H.I. Maibach, J. Pharm. Sci., 95, 1405 (2006); https://doi.org/10.1002/jps.20666.

3. Y. Chen, P. Quan, X. Liu, W. Guo, W. Song, D. Cun, Z. Wang and L. Fang, J. Pharm. Pharmacol., 67, 1232 (2015); https://doi.org/10.1111/jphp.12428.

4. S.E. Cross C. Anderson and M.S. Roberts, Br. J. Clin. Pharmacol., 46, 29 (1998); https://doi.org/10.1046/j.1365-2125.1998.00045.x 
5. V. Adepu, K.E.V. Nagoji and V.G. Sastry, Indo Am. J. Pharm. Res., 6, 6736 (2016).

6. M. Hanif, N. Nazer, V. Chaurasiya and U. Zia, Trop. J. Pharm. Res., 15, 605 (2016); https://doi.org/10.4314/tjpr.v15i3.24.

7. S. Naveed, F. Zafar, H. Ali, H. Dilshad, F. Qamar, S.S. Abbas, N. Waheed, S. Nazeer and Z. Ashraf, Lat. Am. J. Pharm., 34, 1432 (2015).

8. R. Sandip and A.K. Joshi, Int. J. Universal Pharm. Bio. Sci., 3, 1 (2014).

9. B. Rajani and K. Mukkanti, Int. J. Pharm., 4, 309 (2014).

10. G. Patel, P. Chauhan and S. Shah, Am. J. Pharmtech. Res., 4, 658 (2014).

11. I.U. Khan, S.N. Razzaq, I. Mariam, M. Ashfaq and S.S. Razzaq, Quim. Nova, 37, 349 (2014); https://doi.org/10.5935/0100-4042.20140058

12. V. Kokane, S. Bhosale and S. Naik, Int. J. Pharm. Res. Bio-Sci., 4, 341 (2015).

13. M. Tariq, Z. Iqbal, J. Ali, S. Baboota, R. Parveen, M. Mirza, S. Ahmad and J. Sahni, J. Planar Chromatogr., 27, 124 (2014); https://doi.org/10.1556/JPC.27.2014.2.10

14. B. Yilmaz and E. Alkan, Arab. J. Chem.; https://doi.org/10.1016/i.arabic.2014.12.038.

15. J.P. Sapio, K. Sethachutkul and J.E. Moody, J. Pharm. Sci., 68, 506 (1979);

https://doi.org/10.1002/jps.2600680431.
16. V. Adepu and K.E.V. Nagoji, Int. J. Pharm. Pharm. Sci., 6, 31 (2014).

17. P.K. Pradhan, P.N. Rajput, N. Kumar, B. Joshi and U.M. Upadhyay, Int. J. Pharm. Sci. Rev. Res., 27, 96 (2014).

18. G. Patel, P. Chauhan and S. Shah, J. Chem. Pharm. Res., 6, 96 (2014).

19. R.N. Saha, S. Chandran, P.R. Jadhav and P.B. Kharwade, Indian J. Pharm. Sci., 68, 20 (2006); https://doi.org/10.4103/0250-474X.22958.

20. S. Mazurek and R. Szostak, Vib. Spectrosc., 83, 1 (2016); https://doi.org/10.1016/j.vibspec.2015.12.005.

21. D. Dorwal, Int. J. Res. Pharm. Biomed. Sci., 3, 98386 (2012).

22. L. Nováková, D. Solichová and P. Solich, J. Sep. Sci., 29, 2433 (2006); https://doi.org/10.1002/jssc.200600147.

23. R. Dubey, M. Bommagani, V. Venkateswarlu, R. Mullangi, H.R. Karnati, R.K. Thammera and V.C.A. Menon, J. Pain Palliat. Care Pharmacother, 23, 26 (2009); https://doi.org/10.1080/15360280902728062.

24. C. Roy, J. Chakrabarty and P.B. Modi, Indian J. Pharm. Sci., 75, 197 (2013); https://doi.org/10.4103/0250-474X.115468.

25. L. Nováková, L. Matysová, L. Havlíková and P. Solich, J. Pharm. Biomed. Anal., 37, 899 (2005); https://doi.org/10.1016/j.jpba.2004.09.012. 